\title{
Long-term dynamics of stand structure and regeneration in high-stocked selection fir-beech forest stand: Croatian Dinarides case study
}

\author{
Jura Čavlović, \\ Krunoslav Teslak, \\ Karlo Beljan, \\ Mislav Vedriš, \\ Marijana Andabaka
}

\begin{abstract}
In recent decades, changes in stand structure in Central European fir-beech forests, such as accumulation of large-diameter firs, fir dieback, and poor regeneration, have been well documented. Besides environmental factors, light harvesting was suggested as one of the main drivers of the negative structural dynamics of these forests in Croatia. This study applied the MOSES 3.0 stand simulator on permanent sample plot data to reconstruct stand development over the past 20 years and simulate long-term projections of selection stand structure and regeneration with respect to theoretical values, using three management regimes differing by the applied harvesting intensity (traditionally applied, theoretical intensity, and no management). Sample plot data from three sets of detailed measurements $(1992,2002$, and 2012) were used for validation of the simulator, and eleven 10-year cycles of management were then simulated under the above management scenarios. Results showed a positive influence of harvest intensity on stand regeneration and the achievement of a targeted selection structure in the long term. Two management scenarios predicted a decrease in stand volume (34\% and $40 \%$, respectively), an increase in the initial percentage $(28 \%)$ of beech and maple $(58 \%$ and $75 \%$, respectively), and the achievement of optimal stand regeneration of 11-13 recruited trees per hectare annually (60\% firs). No management scenario could achieve old-growth structure (accumulation of standing stock, large trees, and deadwood). The theoretical intensity scenario was evaluated as the better approach to be applied in this type of forest stands in Croatia.
\end{abstract}

Keywords: Selection Harvest, Stand Growth Simulator, Development of DBH Distribution, Tree Species Composition, Natural Regeneration, Old-growth Structure the past to the Dinaric beech-fir mixed forests, which still cover $12 \%$ of total forest area in Croatia, according to the last national forest inventory (CRONFI - Čavlović et al. 2016).

Although the selection management system is known in Croatia since more than a century, it was re-introduced in fir-beech forests (Abieti-Fagetum) after the World War II (Klepac 1961, O'Hara et al. 2018). At that time, Croatian forests were characterized by irregular (transitional) stand structures caused by changes in economic, social, and ownership conditions (Bozić 1999). Accordingly, a management system was established by defining a theoretical (target) stand structure using the "BDq apdating back to the Austro-Hungarian period, and in particular it had been applied in able for Dinaric fir-beech forests as well (Bončina et al. 2002, Čavlović et al. 2006, Bončina 2011), especially because it naturally establishes a selection stand structure (Diaci et al. 2011). Moreover, the selection (Diaci et al. 2011). Moreover, the selection $\square$ Department of Forest Inventory and Management, University of Zagreb, Faculty of Forestry and Wood Technology, Zagreb (Croatia)

@ Krunoslav Teslak (krunoteslak@gmail.com)

Received: Aug 31, 2020 - Accepted: Jul 02, 2021

Citation: Čavlović J, Teslak K, Beljan K, Vedriš M, Andabaka M (2021). Long-term dynamics of stand structure and regeneration in high-stocked selection fir-beech forest stand: Croatian Dinarides case study. iForest 14: 383-392. - doi: 10.3832/ifor3638-014 [online 2021-08-24]

Communicated by: Emanuele Lingua proach" (Klepac 1961, Čavlović et al. 2006), characterized by 10 -year harvesting cycles, each removing up to $25 \%$ of standing volume. The so-called "BDq approach", which has its roots in the work of Meyer (1943), was a common approach for stocking control, where "B" represents the basal area, "D" the maximum target diameter class, and "q" the exponent of the decline function. Achievement or maintenance of a target (reverse- $J$ ) diameter distribution is based on the BDq approach (O'Hara \& Gersonde 2014). However, the stated management principles were applied inconsistently, especially regarding low harvesting intensities, because an actual rate of current volume increment was used instead of a theoretical rate. In such mixed silver fir (Abies alba Mill., hereafter fir) and European beech (Fagus sylvatica L., hereafter beech) stands characterized by irregular structures, a high proportion of large-diameter trees, and a low rate of current volume increment, the commonly applied harvesting intensity was $17 \%$ or less, which neither provided enough canopy openings nor promoted stand regeneration. Therefore, according to the General Forest Management Plan in Dinaric fir-beech forests from 1996 to 2005 , an average harvesting intensity of only $14 \%$ was prescribed. 
In recent decades, several trends in the stand structure development of fir-beech forests have been observed in Croatia (Čavlović et al. 2006) and in other Central European countries (Bončina et al. 2014, Ficko et al. 2011). These changes in stand struc ture can be summarized as follows: (i) in crease of total standing stock; (ii) growing stock accumulation, predominantly of large and low-vitality fir trees; (iii) fir dieback; (iv) poor or non-existent fir regeneration; and (v) an increasing share of beech and maple (Acer pseudoplatanus L.).

The increase in total standing stock and the growing stock accumulation of large and low-vitality firs can be mostly attrib uted to low-intensity management activities, whereas climate change and air pollution are thought to be the main causes of fir dieback (Linares \& Camarero 2012). Furthermore, poor fir regeneration is of special concern (Čavlović et al. 2006, Rozenbergar et al. 2007). In general, environmental factors are considered as the main drivers of fir regeneration dynamics (Safar 1965, Dobrowolska \& Bolibok 2019). However, stand structure and canopy openings should also be taken in consideration as in fluential factors. Čavlović et al. (2006), in a study of Dinaric fir-beech forest characterized by unbalanced stand structures, reported a significant negative correlation between abundance of fir regeneration and large-tree basal area $(\mathrm{DBH}>50 \mathrm{~cm}$ ) Similar stand dynamics were also recorded in the entire Dinaric region (Bončina 2011, Bončina et al. 2014).

Recently, low harvest intensities in Croatian Dinaric fir-beech forests have been addressed as a main driver of such stand dy namics. This assumption led to new regulations for forest management planning in Croatia (Regulations for Forest Manage ment Planning 2006). Hence, to trigger stand regeneration and improve stand structures in selection fir-beech forests, the maximum intensity allowed for 10-year selection felling was set at $30 \%$.

In this forest type, there is a large part (up to one-fourth) of high-stocked stands where two main management objective may be set: (i) providing economic benefits from fir-dominated forests by gradually es tablishing an efficient selection stand struc ture with a growing stock close to or slightly above an equilibrium structure $(\mathrm{Ha}$ newinkel et al. 2014); and (ii) providing a basis for fulfilling the requirements for habitat and nature protection (i.e., Natura 2000 requirements) by maintaining processes that promote an old-growth forest structure (Bauhus et al. 2009, Pirovano \& Zecca 2014). The influence of different management regimes (managed, non-man aged) and approaches (i.e., the traditionally applied lower-intensity approach vs. a moderate-intensity theoretical approach) on long-term stand dynamics could be simulated on previously monitored permanent sample plots representing such a highstocked stand structure.
In this study, we collected data from a permanent sample plot in a mixed firbeech stand in the Croatian Dinarides representing the stand structure and dynamics described above. The MOSES ver. 3.0 stand simulator (Hasenauer et al. 2006) was used to simulate stand dynamics in a selection fir-beech forest stand. The objective was to explore the influences of different selection harvesting intensities on stand structure and regeneration in the long run. Our starting hypotheses were: (i) the MOSES 3.0 stand simulator can accurately simulate fir-beech forest stand dynamics in the Croatian Dinarides; (ii) higher levels of selection harvesting and canopy openings will lead to the achievement of the targeted selection stand structure over the long term; (iii) a more intensive selection management will positively affect stand regeneration dynamics and economic efficiency.

\section{Material and methods}

\section{Study site}

This study was carried out in the Delnice Management Unit (MU) located on a mildly sloping mountain range in the Gorski kotar region (Western Croatia). The MU is representative of a typical selection fir-beech mountain forest (Abieti-Fagetum). Inventory data from a permanent sample plot $(60 \times 60 \mathrm{~m})$ were used. The plot is situated within the $\mathrm{MU}\left(45^{\circ} 23^{\prime} 10^{\prime \prime} \mathrm{N}, 14^{\circ} 46^{\prime} 05^{\prime \prime} \mathrm{E}\right.$; elevation $700 \mathrm{~m}$ a.s.l.) oriented in a southeasterly direction with an inclination of $20^{\circ}$ to $40^{\circ}$ (Fig. S1 in Supplementary material).

The experimental plot is located on limestone and dolomite bedrock with mountain chernozem and acid brown soils, and is representative of a larger area with similar vegetation and soil characteristics. The uneven-aged forests in the Gorski kotar area are characterized by irregular diameter structure of selection stands and poor natural regeneration. Species composition is dominated by fir ( $43 \%$ ) and beech (40\%), followed by Norway spruce (Picea abies Karst. $-10 \%$ ) and maple (6\%). More detailed information about the stand structure and characteristics is reported in Tab. S1 (Supplementary material).

The prevalent climate in the area is temperate and moist, with a mean annual temperature of $7.6^{\circ} \mathrm{C}$. The mean monthly temperature does not exceed $28^{\circ} \mathrm{C}$ in the summer. Air humidity is high during the entire year and reaches a maximum in February (92\%). Annual rainfall varies between 1500 and $2500 \mathrm{~mm}$, and the snow period lasts 188 days, on average. Data were provided by the Cabar-Parg weather station $\left(45.6^{\circ} \mathrm{N}\right.$, $14.63^{\circ} \mathrm{E} ; 863 \mathrm{~m}$ a.s.l.) where meteorological records are collected since 1943.

\section{Data collection}

The permanent sample plot was established in 1992 and inventoried every 10 years (first in 1992, and subsequently in 2002 and 2012) after selective felling. De- tailed measurements and assessments in cluded trees with diameter at breast height $(\mathrm{DBH}) \geq 10 \mathrm{~cm}$ (numbering and tagging, tree species, diameter at breast height, tree height, height of crown base, tree position in local coordinate system, tree vitality). Diameter at breast height was measured for saplings and young trees (DBH 0.1 to $10 \mathrm{~cm}$ ), whereas seedlings were counted into two height classes: small (0.1 to $0.5 \mathrm{~m}$ ) and tall seedlings ( 0.51 to $1.3 \mathrm{~m}$ ). All cut trees and their year of harvest were recorded using data from previous inventory, tree position, and assessment of stumps. The obtained stand characteristics and trends (Tab. 1) were used to analyze the past development of stand structure for validation of the stand simulator, and to simulate future stand structure (initial state 2012 inventory).

\section{Data analysis}

According to data from the first national forest inventory in the Republic of Croatia (CRONFI - Čavlović et al. 2016), there is a significant number of well-stocked selection fir-beech stands in the Gorski kotar region. They are characterized by overstocking with a large portion of large tree diameter class $(\mathrm{DBH}>50 \mathrm{~cm})$ and poor stand regeneration, especially of firs, on approximately one-fourth of the forest area (Tab. S1 in Supplementary material), because of low selection harvests carried out in the past few decades (Čavlović et al. 2006). The stand structure observed (Tab. 1) was assumed to be appropriate for simulations and stand structure projections, as it represents one-fourth of the best-stocked stands of this type in the region.

In the 2012 inventory, 222 trees with DBH $\geq 5 \mathrm{~cm}$ were recorded in the permanent sample plot. Diameter class distribution, basal area, and growing volume per $5-\mathrm{cm}$ DBH class (as well as three wider diameter classes: small, $10 \leq \mathrm{DBH}<30 \mathrm{~cm}$; medium, $30 \leq \mathrm{DBH}<50 \mathrm{~cm}$; large, $\mathrm{DBH} \geq 50 \mathrm{~cm}$ ) were determined for trees with $\mathrm{DBH} \geq 10$ $\mathrm{cm}$. The mean height of 16 dominant firs (one-fifth of the highest firs in the large-diameter class, $\geq 50 \mathrm{~cm}$ ) was $36.2 \mathrm{~m}$, and that of 15 dominant beech trees (half the highest beech trees in the $31-50 \mathrm{~cm}$ diameter class) was $30.7 \mathrm{~m}$. By applying dominant heights and the BDq approach, theoretical (target) reverse-J diameter distributions were determined according to traditional uneven-aged forest management practice in Croatia (Klepac 1961, Čavlović et al. 2006). Thus, the parameters of the target model for the mixed selection fir-beech stand with $80 \%$ and $20 \%$ of the total growing volume (GV $=403.0 \mathrm{~m}^{3} \mathrm{ha}^{-1}$ at half $\mathrm{cy}$ cle), were determined using the theoretical distribution of fir, which was defined by $q=$ 1.30, $D_{\max }$ (maximum tree diameter) $=70$ $\mathrm{cm}, \mathrm{BA}$ (basal area) $=35.1 \times 0.80=28.1 \mathrm{~m}^{2}$ $\mathrm{ha}^{-1}$, and that of beech, defined by $q=1.45$, $D_{\max }=50 \mathrm{~cm}, B A=22.4 \times 0.20=4.5 \mathrm{~m}^{2} \mathrm{ha}^{-1}$, with total $B A=32.6 \mathrm{~m}^{2} \mathrm{ha}^{-1}$.

The MOSES 3.0 stand growth simulator 
(Hasenauer et al. 2006) was used to simulate selection stand structure development. This software had been previously used for growth modeling (including mortality probabilities) of fir-beech stands in Croatia (Mikac et al. 2013). The simulator was adapted to the local volume equations according to Spiranec (1976). Validation was performed by comparing the simulated standing volumes with the inventory data. The year 1992 was taken as the base year, and comparison of standing volumes was made after 10 years (2002) and subsequently after 20 years (2012). A paired $t$ test $(\alpha=0.05)$ was applied to test for differences in standing volume $(\Delta \mathrm{V})$ between the observed (inventory) and simulated data, with the following outcome: fir (19922002: $\Delta \mathrm{V}=2.14 \mathrm{~m}^{3} \mathrm{ha}^{-1}, \mathrm{p}=0.1671 ; 1992-$ 2012: $\left.\Delta \mathrm{V}=2.71 \mathrm{~m}^{3} \mathrm{ha}^{-1}, \mathrm{p}=0.4204\right)$, beech (1992-2002: $\Delta V=1.03 \mathrm{~m}^{3} \mathrm{ha}^{-1}, \mathrm{p}=0.1211$; 1992-2012: $\left.\Delta \mathrm{V}=2.07 \mathrm{~m}^{3} \mathrm{ha}^{-1}, \mathrm{p}=0.11187\right)$, and total $\Delta \mathrm{V}$ (1992-2002: $\Delta \mathrm{V}=0.29 \mathrm{~m}^{3} \mathrm{ha}^{-1}, \mathrm{p}$ $=0.928 ; 1992-2012: \Delta \mathrm{V}=2.08 \mathrm{~m}^{3} \mathrm{ha}^{-1}, \mathrm{p}=$ $0.5815)$. According to the small and nonsignificant differences obtained between observed and simulated volumes, it was assumed that the simulation of future stand development would perform in a similar and consistent way also for comparison of different future scenarios.

Besides stand regeneration (tree recruitment), tree increment, and mortality, the amount of harvest and its distribution among diameter classes were considered as main drivers affecting selection stand structure and development. Harvesting changes the diameter structure and consequently the pattern of tree growth and regeneration. Hence, three management scenarios were developed using different approaches to prescribe harvest volume.

\section{Scenario 1}

The reference scenario (Scenario 1) was based on the common approach of prescribing a harvest volume (eqn. 1):

$$
H A_{s c 1}=S V_{a c t} \cdot\left(1-\frac{1}{1.0 p^{l}}\right) \cdot \frac{S V_{a c t}}{G V_{\text {theor }}}
$$

where $H A_{s c 1}$ is the harvest amount according to Scenario $1\left(\mathrm{~m}^{3} 10-\mathrm{yr} \mathrm{r}^{-1}\right), \mathrm{SV}_{\text {act }}$ is the ac- tual total standing volume before harvest $\left(\mathrm{m}^{3} \mathrm{ha}^{-1}\right), G V_{\text {theor }}$ is the theoretical total growing volume before cut $\left(\mathrm{m}^{3} \mathrm{ha}^{-1}\right)$ based on the developed BDq model (see above), I is the length of the harvest cycle (10 years), and $p$ is the rate (\%) of current annual volume increment; instead of a theoretical value, an actual rate has traditionally been applied, leading to low harvest intensities.

The scenario was chosen because this approach has been used for operational forest management and planning of selection fir-beech forests during the last 70 years.

\section{Scenario 2}

As an alternative to the reference scenario, the Hundeshagen formula was chosen as a method for estimating sustainable harvests (Bettinger et al. 2009). According to the method, continuous application of the theoretical rate of current annual volume increment on actual standing volume would lead to achieve the theoretical (i.e., desired) growing volume with a balanced structure over the long term. Hence, Scenario 2 is based on a theoretical harvest in-

Tab. 1 - Observed data of stand structure and harvest by diameter classes $(10-30 \mathrm{~cm}, 31-50 \mathrm{~cm},>50 \mathrm{~cm}$ of DBH) and structure of stand regeneration, according to tree species and inventories (years 1992, 2002 and 2012). Stand structure values refer to state before harvest, for 2002 and 2012 inventories values in brackets refer to harvest amounts in each DBH class. (N): number of trees; (BA): basal area; (SV): standing volume; (DBH): average diameter at breast height; (Ss): small seedlings (height $\leq 0.50 \mathrm{~m})$; (Ts): tall seedlings (0.51-1.30 m); (Sap): saplings (0.1-5.0 cm of DBH); (Yt): young trees (5.1-10.0 cm of DBH); (na): not available.

\begin{tabular}{|c|c|c|c|c|c|c|c|c|c|c|c|c|c|}
\hline \multirow{2}{*}{ 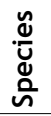 } & \multirow[b]{2}{*}{ Parameter } & \multicolumn{4}{|c|}{ Year 1992} & \multicolumn{3}{|c|}{ Year 2002} & \multicolumn{3}{|c|}{ Year 2012} & \multirow[b]{2}{*}{$\begin{array}{r}>50 \\
\mathrm{~cm}\end{array}$} & \multirow[b]{2}{*}{ Total } \\
\hline & & $\begin{array}{r}10-30 \\
\mathrm{~cm}\end{array}$ & $\begin{array}{r}31-50 \\
\mathrm{~cm}\end{array}$ & $\begin{array}{l}>50 \\
\mathrm{~cm}\end{array}$ & Total & $\begin{array}{r}10-30 \\
\mathrm{~cm}\end{array}$ & $\begin{array}{r}31-50 \\
\mathrm{~cm}\end{array}$ & $\begin{array}{l}>50 \\
\mathrm{~cm}\end{array}$ & Total & $\begin{array}{r}10-30 \\
\mathrm{~cm}\end{array}$ & $\begin{array}{r}31-50 \\
\mathrm{~cm}\end{array}$ & & \\
\hline \multirow{8}{*}{$\frac{i}{\stackrel{D}{亠}}$} & $N\left(h^{-1}\right)$ & 25 & 36 & 78 & 139 & $26(6)$ & $22(0)$ & $92(11)$ & $140(17)$ & $23(6)$ & $22(3)$ & 81 (14) & $126(22)$ \\
\hline & $\mathrm{BA}\left(\mathrm{m}^{2} \mathrm{ha}^{-1}\right)$ & 0.9 & 5 & 22.8 & 28.6 & $1.1(0.3)$ & $2.9(0)$ & $28.6(4.0)$ & $32.5(4.3)$ & $0.9(0.2)$ & $3.4(0.5)$ & $27.6(6.6)$ & $31.8(7.2)$ \\
\hline & $\mathrm{SV}\left(\mathrm{m}^{3} \mathrm{ha}^{-1}\right)$ & 9 & 71 & 381 & 461 & $11(4)$ & $41(0)$ & $493(72)$ & $546(76)$ & $10(1)$ & $51(8)$ & $490(122)$ & 551 (131) \\
\hline & $\mathrm{DBH}(\mathrm{cm})$ & 21 & 41.48 & 60.58 & - & 20.28 & 40.46 & 61.86 & - & 22.65 & 43.41 & 63.02 & - \\
\hline & Ss $\left(\mathrm{ha}^{-1}\right)$ & - & - & - & na & - & - & - & 0 & - & - & - & 0 \\
\hline & Ts $\left(h^{-1}\right)$ & - & - & - & na & - & - & - & 0 & - & - & - & 0 \\
\hline & Sap $\left(h^{-1}\right)$ & - & - & - & 0 & - & - & - & 0 & - & - & - & 0 \\
\hline & Yt $\left(h^{-1}\right)$ & - & - & - & 3 & - & - & & 32.5 (4.3) & - & - & - & 0 \\
\hline \multirow{8}{*}{ 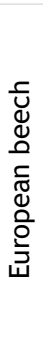 } & $N\left(h^{-1}\right)$ & 319 & 8 & 0 & 327 & $339(58)$ & $22(0)$ & $0.0(0)$ & $361(58)$ & 297 (53) & $30(8)$ & $0(0)$ & $327(61)$ \\
\hline & BA $\left(m^{2} h a^{-1}\right)$ & 6.7 & 0.7 & 0 & 7.3 & $7.8(1.4)$ & $2.0(0)$ & $0.0(0)$ & $9.8(1.4)$ & $7.6(1.4)$ & $3.4(1.1)$ & $0(0)$ & $11.1(2.5)$ \\
\hline & SV $\left(m^{3} h^{-1}\right)$ & 52 & 8 & 0 & 60 & $71(12)$ & $27(0)$ & $0.0(0)$ & $97(12)$ & $81(14)$ & $52(17)$ & $0(0)$ & $133(31)$ \\
\hline & $\mathrm{DBH}(\mathrm{cm})$ & 15.62 & 31.92 & - & - & 16.41 & 33.47 & - & - & 17.18 & 36.46 & - & - \\
\hline & Ss $\left(\mathrm{ha}^{-1}\right)$ & - & - & - & na & - & - & - & 44 & - & - & - & 45 \\
\hline & Ts $\left(h^{-1}\right)$ & - & - & - & na & - & - & - & 55 & - & - & - & 48 \\
\hline & Sap $\left(\mathrm{ha}^{-1}\right)$ & - & - & - & 4 & - & - & - & 69 & - & - & - & 61 \\
\hline & Yt $\left(\mathrm{ha}^{-1}\right)$ & - & - & - & 194 & - & - & - & 152 & - & - & - & 122 \\
\hline \multirow{8}{*}{ 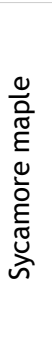 } & $N\left(h^{-1}\right)$ & 22 & 22 & 6 & 50 & $11(3)$ & $34(6)$ & $6(3)$ & $51(12)$ & $6(3)$ & $31(3)$ & $3(0)$ & $40(6)$ \\
\hline & $\mathrm{BA}\left(\mathrm{m}^{2} \mathrm{ha}^{-1}\right)$ & 1 & 2.3 & 1.1 & 4.3 & $0.4(0.1)$ & $3.5(0.7)$ & $1.2(0.6)$ & $5.2(1.3)$ & $0.2(0.1)$ & $3.4(0.3)$ & $0.7(0.0)$ & $4.4(0.4)$ \\
\hline & $\mathrm{SV}\left(\mathrm{m}^{3} \mathrm{ha}^{-1}\right)$ & 10 & 30 & 18 & 59 & $5(0)$ & $58(11)$ & $11(10)$ & $73(20)$ & $3(0)$ & $57(5)$ & $13(0)$ & $72(6)$ \\
\hline & $\mathrm{DBH}(\mathrm{cm})$ & 22.53 & 35.84 & 50.88 & - & 8.61 & 22.52 & 37.61 & - & 27.55 & 37.38 & 58.15 & - \\
\hline & Ss $\left(\mathrm{ha}^{-1}\right)$ & - & - & - & na & - & - & - & 155 & - & - & - & 156 \\
\hline & Ts $\left(h^{-1}\right)$ & - & - & - & na & - & - & - & 3 & - & - & - & 3 \\
\hline & Sap $\left(h a^{-1}\right)$ & - & - & - & 0 & - & - & - & 0 & - & - & - & 0 \\
\hline & Yt $\left(\mathrm{ha}^{-1}\right)$ & - & - & - & 3 & - & - & - & 0 & - & - & - & 3 \\
\hline \multirow{3}{*}{ 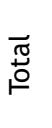 } & $N\left(h^{-1}\right)$ & 366 & 66 & 84 & 516 & $376(67)$ & $78(6)$ & $98(14)$ & $552(87)$ & $326(62)$ & $83(14)$ & $84(14)$ & $493(89)$ \\
\hline & $\mathrm{BA}\left(\mathrm{m}^{2} \mathrm{ha}^{-1}\right)$ & 8.5 & 7.9 & 23.9 & 40.3 & $9.3(1.7)$ & $8.4(0.7)$ & $29.8(4.6)$ & $47.5(7.0)$ & $8.7(1.7)$ & $10.3(1.9)$ & $28.3(6.6) 4$ & $47.3(10.1)$ \\
\hline & $S V\left(m^{3} h a^{-1}\right)$ & 71 & 110 & 399 & 579 & $87(16)$ & $125(11)$ & $504(82)$ & 716 (109) & $93(16)$ & $159(30)$ & $503(121.82)$ & $755(168)$ \\
\hline
\end{tabular}


tensity using the theoretical rate of current annual volume increment and the harvest cycle length (eqn. 2):

$$
H A_{s c 2}=S V_{a c t} \cdot h I_{T}
$$

where $h l_{T}$ is the theoretical 10-year harvest intensity (25.4\%), and a 10-year harvest cycle and a $2.54 \%$ rate of theoretical current annual volume increment based on the developed $\mathrm{BDq}$ model were used. Theoretical harvest intensity and the rate of mean annual volume increment were based on theoretical growing volume before harvest.

\section{Scenario 3}

A third scenario (Scenario 3) simulated the future dynamics of the study stand where only natural processes (tree growth, tree death, and stand regeneration) take place and no management activities are carried out.

\section{Simulations}

Stand structure development was simulated for 11 future decades with a 10-year cycle and directed (in scenarios 1 and 2) to the target model for the mixed selection stand of fir and beech. For all scenarios at the end of each simulation step, tree attributes (species, age, DBH, and height) as well as stand variables per hectare (number of trees, basal area, growing volume, volume increment, number of dead trees, and the annual recruitment of young trees that exceed the threshold of $\mathrm{DBH}=10 \mathrm{~cm}$ ) were recorded.

For the first two scenarios, the total harvest volume was calculated at the end of each cycle (eqn. 1, eqn. 2). After each simulation step, canopy opening in the stand was simulated by marking trees to be felled according to the following criteria: (i) gradual harvesting of overmature firs; (ii) favoring fir regeneration and recruitment; (iii) leaving high-value broadleaf trees (maple); (iv) achieving and maintaining a balanced selection stand structure, regeneration, and increment. Trees to be felled were selected by visual inspection based on the spatial distribution of the simulated stand (Fig. 1). Total harvest volume was calculated according to tree species and size using projected data (i.e., height, $\mathrm{dbh}$, volume). Targeted and simulated numbers of trees were compared within each DBH class and species. Overall volume of all marked trees should be equal or close to the calculated harvest volume.

\section{Evaluation of management scenarios}

Indicators of management and stand structure variables predicted by simulations in relation to the theoretical (target) values were used to compare and evaluate the three scenarios described above.

Deviations of the projected values of management variables (harvest volume, harvest intensity, rate of current annual increment, and net present value) from theoretical values of the target $\mathrm{BDq}$ model were estimated by calculating the following indices (eqn. 3):

$$
I_{D E V}=\frac{\sum_{t=1}^{11}\left|X_{S C_{t}}-X_{N_{t}}\right|}{\sum_{t=1}^{11} X_{N_{t}}}
$$

where $t$ is the number of periods (simulation steps), $X_{s c t}$ is the projected value at each simulation step, and $X_{\mathrm{Nt}}$ is the theoretical value according to the target $\mathrm{BDq}$ model. The smaller the overall deviation from the target value, the better was the scenario rank.

Stand structural variables (volume of small, medium and large fir/beech trees, current annual volume increment and recruitment of fir/beech trees simulated in the last three cycles) averaged over cycles were used to calculate the indices of achievement of the targeted stand structure at the end of simulation period. The rate of volume increase of the three diameter classes (small, medium, and large) for fir and beech/other broadleaves was calcu-
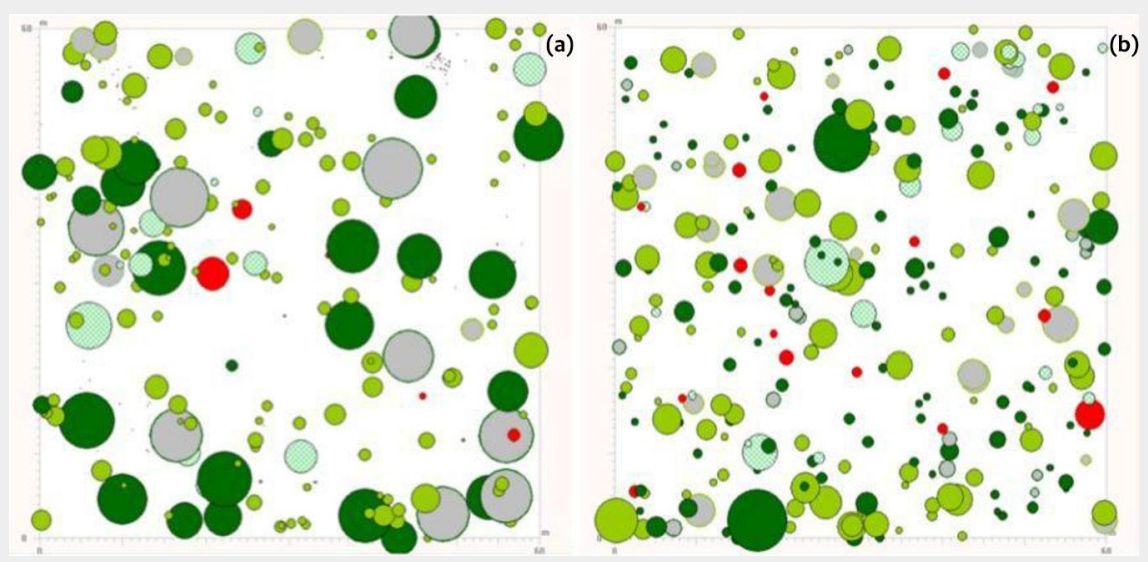

Fig. 1 - Spatial distribution of tree species within the studied sample plot according to Scenario 1: (a) first simulation step; (b) $11^{\text {th }}$ simulation step. Silver fir is represented by dark green circles, beech by light green circles, Sycamore by dotted pattern, dead trees by red fill, and grey fill denotes trees designated to be felled. lated as the average of simulated values in the last three cycles, and compared to the theoretical rates. The average simulated values of the rates of current annual volume increment and tree recruitment for the two species were also calculated for the last three cycles and compared with their theoretical values.

The software STATISTICA ${ }^{\oplus}$ v. 13.0 (StatSoft Inc., Tulsa, OK, USA) was used for validation of the growth simulator by paired $t$ tests, while the Excel $^{\oplus}$ package (Microsoft Corp., Redmond, WA, USA) was used for the statistical evaluation of management scenarios.

\section{Results}

Stand dynamics over the period 1992-2012 (Tab. 1) was characterized by an increased standing volume (from $579.4 \mathrm{~m}^{3} \mathrm{ha}^{-1}$ to $\left.755.5 \mathrm{~m}^{3} \mathrm{ha}^{-1}\right)$ and increased share of broad leaf species (beech and sycamore maple, from $20.4 \%$ to $27 \%$ ) based on the 2012 inventory (before felling). During this period, the standing volume of large firs $(\mathrm{DBH}>50 \mathrm{~cm})$ increased from the initial $381 \mathrm{~m}^{3} \mathrm{ha}^{-1}(82.6 \%$ of the total standing volume of firs) to 490 $\mathrm{m}^{3} \mathrm{ha}^{-1}(89 \%)$. Management was characterized by a low felling intensity (only $15 \%$ in 2002), although felling intensity increased to $22.3 \%$ in 2012 , aimed to remove large, overmature, and low-vitality firs as well as large beech trees. The diameter structure and the absence of small-diameter firs indicate poor fir regeneration during a long period in the past, as well as poor recent regeneration, with no seedlings, saplings, or young firs observed in the sample plot. Unlike fir, beech and sycamore showed a fairly good regeneration (Tab. 1).

The observed dynamics of stand structure at the study plot during the 20-year period (Tab. 1) reflects the highest-stocked fir-beech forests in the Gorski kotar region and the Croatian Dinarides, as well as forest management in the last 70 years. An accumulated standing volume of large-diameter firs, poor fir regeneration, and low selection harvesting intensities are the main characteristics. According to CRONFI, the average standing volume at the study plot ( $579 \mathrm{~m}^{3} \mathrm{ha}^{-1}$ - Tab. 1) was 1.6 times higher than that of the entire forest type (364.9 $\mathrm{m}^{3} \mathrm{ha}^{-1}$ ) and higher than that of the same forest type over the whole Gorski kotar region (417.5 $\mathrm{m}^{3} \mathrm{ha}^{-1}-$ Tab. S1 in Supplementary material), which is reasonable given the different spatial scales considered. However, a similar number of large-diameter trees $(\mathrm{DBH}>50 \mathrm{~cm})$ was observed both in the Gorski kotar region and at the study plot, with a share of $48 \%$ vs. $65 \%$ of total standing volume, respectively (Tab. 1, Tab. $\mathrm{S} 1$ in Supplementary material). This is much higher than what expected based on the theoretical structure $(33 \%$ of the total growing volume). Similar results were obtained in terms of poor fir regeneration (Tab. 1). Over the period 1996-2005, the average harvest intensity prescribed in these stands was only $14 \%$, while the actual inten- 
Tab. 2 - Trend and structure of standing volume, harvests and 10-year volume increment during the 11 cycles of the simulation period according to different scenarios. (DTr): volume of dead trees during last 10-year period; (MDT): medium-diameter trees (DBH 30-50 $\mathrm{cm})$; (LDT): large-diameter trees ( $\mathrm{DBH}>50 \mathrm{~cm}$ ); (1): for standing volume and 10-year harvesting intensity the average values for the simulation period are shown; (2): for Scenarios 1 and 2, $H A_{s c}$ includes the volume of trees marked to harvest and that of dead trees during last 10-year period, while for Scenario $3 \mathrm{HA}_{\mathrm{sc}}$ has relative meaning and presents dead trees during last 10-year period; (3): 10year gross volume increment includes net 10-year volume increment and volume of dead trees during the last 10-year period.

\begin{tabular}{|c|c|c|c|c|c|c|c|c|c|c|}
\hline \multirow{3}{*}{$\begin{array}{c}\text { Cycle } \\
\text { (end year) }\end{array}$} & \multirow{3}{*}{ Scenario } & \multicolumn{3}{|c|}{ Standing volume } & \multicolumn{4}{|c|}{ Harvest ${ }^{(2)}$} & \multicolumn{2}{|c|}{ 10-year increment ${ }^{(3)}$} \\
\hline & & \multirow{2}{*}{$\begin{array}{c}S V_{\text {act }} \\
\left(\mathrm{m}^{3} \mathrm{ha}^{-1}\right)\end{array}$} & \multicolumn{2}{|c|}{ Share in $S V_{\text {act }}$} & \multirow{2}{*}{$\begin{array}{c}H A_{s c} \\
\left(\mathrm{~m}^{3} \mathrm{ha}^{-1}\right)\end{array}$} & \multicolumn{2}{|c|}{ Share in $H A_{s c}$} & \multirow{2}{*}{$\begin{array}{l}h l_{10} \\
(\%)\end{array}$} & \multirow{2}{*}{$\begin{array}{c}\text { Gross } \\
\left(\mathrm{m}^{3} \mathrm{ha}^{-1}\right)\end{array}$} & \multirow{2}{*}{$\begin{array}{c}\text { Net } \\
\left(\mathrm{m}^{3} \mathrm{ha}^{-1}\right)\end{array}$} \\
\hline & & & $\begin{array}{c}\text { Fir / DTr } \\
\text { (\%) }\end{array}$ & $\begin{array}{c}\text { MDT / LDT } \\
(\%)\end{array}$ & & $\begin{array}{c}\text { Fir / DTr } \\
\text { (\%) }\end{array}$ & $\begin{array}{l}\text { MDT /LDT } \\
(\%)\end{array}$ & & & \\
\hline \multirow[t]{3}{*}{ I (2022) } & 1 & 743.6 & $69 / 4$ & $21 / 66$ & 244.4 & $81 / 14$ & $16 / 81$ & 32.9 & 151.7 & 118.4 \\
\hline & 2 & 747.8 & $69 / 4$ & $25 / 54$ & 189.3 & $62 / 17$ & $23 / 75$ & 25.4 & 156 & 124.2 \\
\hline & 3 & 741.2 & $69 / 7$ & $22 / 66$ & 49.3 & $81 / 100$ & $18 / 63$ & 6.6 & 150.6 & 101.8 \\
\hline \multirow[t]{3}{*}{ II (2032) } & 1 & 628.9 & $60 / 4$ & $24 / 61$ & 176 & $67 / 14$ & $22 / 73$ & 28.1 & 129.5 & 104.2 \\
\hline & 2 & 697.7 & $68 / 2$ & $23 / 70$ & 175.1 & $55 / 7$ & $41 / 55$ & 25.1 & 139.4 & 126.5 \\
\hline & 3 & 838 & $66 / 8$ & $23 / 66$ & 70.9 & $56 / 100$ & $21 / 72$ & 8.4 & 145.6 & 75.1 \\
\hline \multirow[t]{3}{*}{ III (2042) } & 1 & 566.5 & $54 / 8$ & $26 / 55$ & 138 & 77 / 31 & $11 / 79$ & 24.5 & 112.8 & 69.4 \\
\hline & 2 & 651.1 & $69 / 2$ & $21 / 64$ & 163.9 & $64 / 6$ & $27 / 64$ & 25.2 & 128.1 & 117.6 \\
\hline & 3 & 904.9 & $65 / 11$ & $21 / 68$ & 98.9 & $51 / 100$ & $36 / 46$ & 10.9 & 137.6 & 38.6 \\
\hline \multirow[t]{3}{*}{ IV (2052) } & 1 & 532.2 & $44 / 10$ & $28 / 49$ & 117.7 & $60 / 46$ & $22 / 69$ & 22.3 & 102.5 & 48 \\
\hline & 2 & 600.4 & $67 / 6$ & $19 / 64$ & 151.4 & $63 / 24$ & $18 / 70$ & 25.3 & 112.6 & 76.2 \\
\hline & 3 & 930 & $65 / 8$ & $17 / 72$ & 79.6 & $49 / 100$ & 27 / 59 & 8.5 & 124 & 45 \\
\hline \multirow[t]{3}{*}{ V (2062) } & 1 & 517.7 & $36 / 1$ & $39 / 40$ & 113.3 & $26 / 6$ & $67 / 25$ & 22.1 & 102 & 95.5 \\
\hline & 2 & 558.6 & $63 / 1$ & $24 / 62$ & 140.1 & $65 / 5$ & $25 / 65$ & 25.2 & 109.2 & 101.7 \\
\hline & 3 & 976.3 & $64 / 8$ & $16 / 75$ & 78.1 & $21 / 100$ & $37 / 41$ & 8 & 125.3 & 47.6 \\
\hline \multirow[t]{3}{*}{ VI (2072) } & 1 & 503.3 & $36 / 13$ & $36 / 42$ & 106.2 & 42 / 61 & $27 / 65$ & 21.3 & 98.1 & 32.9 \\
\hline & 2 & 523.2 & $58 / 3$ & $27 / 58$ & 129.7 & 49 / 12 & $45 / 47$ & 24.9 & 103.7 & 88.6 \\
\hline & 3 & 1018.6 & $66 / 8$ & $15 / 78$ & 84.4 & $45 / 100$ & $16 / 60$ & 8.3 & 119.9 & 35.8 \\
\hline \multirow[t]{3}{*}{ VII (2082) } & 1 & 497.5 & $33 / 5$ & $41 / 35$ & 108.5 & 29 / 24 & $44 / 41$ & 22.1 & 99.9 & 73.7 \\
\hline & 2 & 489.8 & $55 / 8$ & $25 / 58$ & 122.6 & $68 / 32$ & $21 / 67$ & 25.2 & 95.4 & 56.1 \\
\hline & 3 & 1040.2 & $65 / 9$ & $18 / 78$ & 91.4 & $53 / 100$ & $24 / 70$ & 8.8 & 105.7 & 14.3 \\
\hline \multirow[t]{3}{*}{ VIII (2092) } & 1 & 492.9 & $32 / 2$ & $42 / 32$ & 110.1 & $33 / 8$ & $46 / 41$ & 22.6 & 103 & 94 \\
\hline & 2 & 467 & $46 / 2$ & $30 / 51$ & 120.9 & $28 / 9$ & $47 / 47$ & 26.1 & 100.9 & 89.8 \\
\hline & 3 & 1047.8 & $64 / 7$ & $15 / 80$ & 72.4 & $39 / 100$ & $29 / 56$ & 6.9 & 99 & 26.6 \\
\hline \multirow[t]{3}{*}{ IX ( 2102) } & 1 & 486.4 & $30 / 6$ & $44 / 28$ & 108.1 & $35 / 26$ & $55 / 29$ & 22.6 & 102.9 & 75.1 \\
\hline & 2 & 481.3 & $45 / 5$ & $11 / 77$ & 114.5 & $51 / 20$ & $37 / 50$ & 25.8 & 102.4 & 79.7 \\
\hline & 3 & 1066 & $63 / 8$ & $12 / 83$ & 84.7 & $66 / 100$ & $16 / 81$ & 7.9 & 90.6 & 5.8 \\
\hline \multirow[t]{3}{*}{$X(2112)$} & 1 & 483.6 & $28 / 6$ & $45 / 27$ & 108.2 & 37 / 27 & $39 / 41$ & 22.7 & 104.3 & 75 \\
\hline & 2 & 444.7 & $42 / 5$ & $37 / 42$ & 112.6 & $34 / 18$ & $55 / 27$ & 25.7 & 109.8 & 89.3 \\
\hline & 3 & 1083.9 & $60 / 4$ & $13 / 82$ & 39.4 & $2 / 100$ & $18 / 67$ & 3.6 & 102.6 & 63.3 \\
\hline \multirow[t]{3}{*}{ XI (2122) } & 1 & 494.4 & $25 / 5$ & $53 / 19$ & 111 & $12 / 22$ & $71 / 0$ & 23.4 & 107 & 82.7 \\
\hline & 2 & 450.3 & $42 / 3$ & $38 / 41$ & 112.4 & $62 / 13$ & $18 / 76$ & 25.3 & 117.7 & 102.8 \\
\hline & 3 & 1111.6 & $61 / 3$ & $14 / 81$ & 33 & $6 / 100$ & $28 / 43$ & 3 & 67.1 & 34.1 \\
\hline \multirow[t]{3}{*}{ Overall (1) } & 1 & 540.6 & $41 / 6$ & $36 / 41$ & 1442 & $50 / 24$ & $35 / 54$ & 24 & 1214 & 869 \\
\hline & 2 & 555.6 & $57 / 4$ & $26 / 58$ & 1532 & $56 / 15$ & $32 / 60$ & 25.4 & 1275 & 1053 \\
\hline & 3 & 978.1 & $64 / 7$ & $17 / 75$ & 782 & $43 / 100$ & $24 / 60$ & 7.4 & 1268 & 488 \\
\hline
\end{tabular}

sity was $17 \%$, which is within the allowed $20 \%$ discrepancy. However, an average harvest of $76.5 \mathrm{~m}^{3} \mathrm{ha}^{-1} 10 \mathrm{yr}^{-1}$ (intensity of $21 \%$ ) assessed in the first national forest inventory and corresponding to the plan for 2006-2015 indicated a gradual increase in harvest intensity during the last two decades.

Results of the simulated stand structure achieved by harvesting in eleven successive 10-year cycles are reported in Tab. 2 . Compared to previous management car- ried out in the studied stand, absolute and relative harvest amounts would be considerably increased during the first three harvest cycles, especially in the reference Scenario 1. The main differences among the simulated management scenarios reflect the different 10-year harvest intensity applied. A continuous intensity of about $25 \%$ would normally be applied in Scenario 2, whereas the reference Scenario 1 would start with a maximum intensity of $32.9 \%$, gradually decrease to $22.3 \%$ in the fourth cycle, and continue between $22 \%$ and $23 \%$ in the next cycles (Tab. 2). On the other hand, in the Scenario 3 (no management), the volume of living trees during the simulation period (110 years) would be reduced by tree mortality, with the volume of dead trees increasing on average by $7.4 \%$ in every 10-years period (Tab. 2 ).

Because 10-year harvests including volumes of dead trees are larger by an average of $19 \%$ than the gross 10 -year increment (especially in the first four cycles), a 

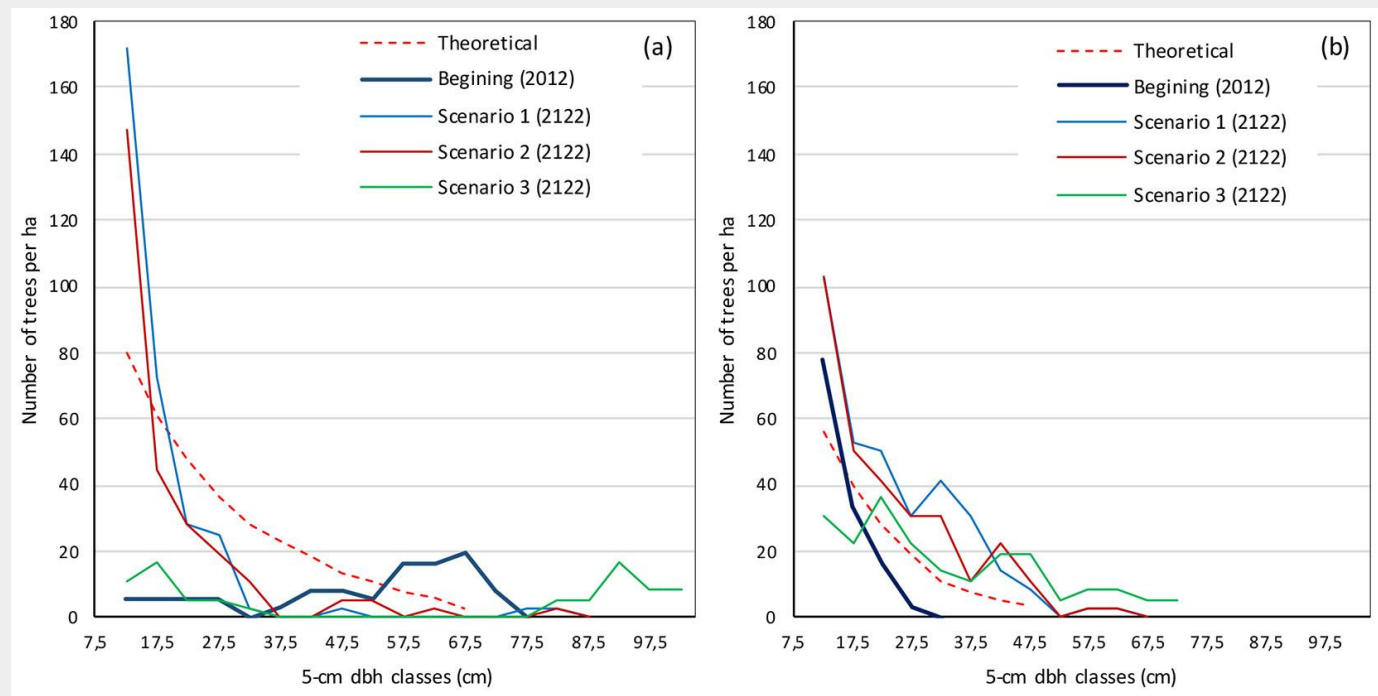

Fig. 2 - Theoretical and simulated DBH distributions (values after harvest) under different management scenarios over the period 2012-2122 for (a) Silver fir and (b) European beech and other broadleaves; (c) stand recruitment under different simulated scenarios over the same period (thin lines: Silver fir; bold lines: total recruitment); (d) trend of standing dead wood and diameter structure by different scenarios (orange bars: beech and other broadleaves; dark green

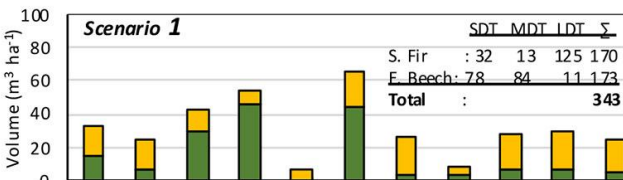
bars: Silver Fir); numbers show the overall amount of standing dead wood by diameter class (SDT: 10-30 cm, MDT: 30-50 cm; LDT:

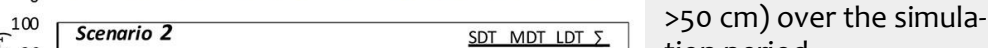

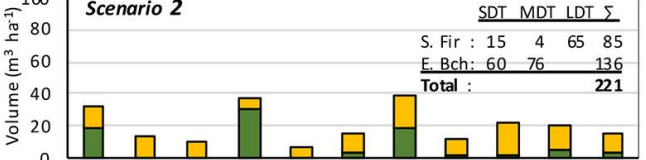
tion period.
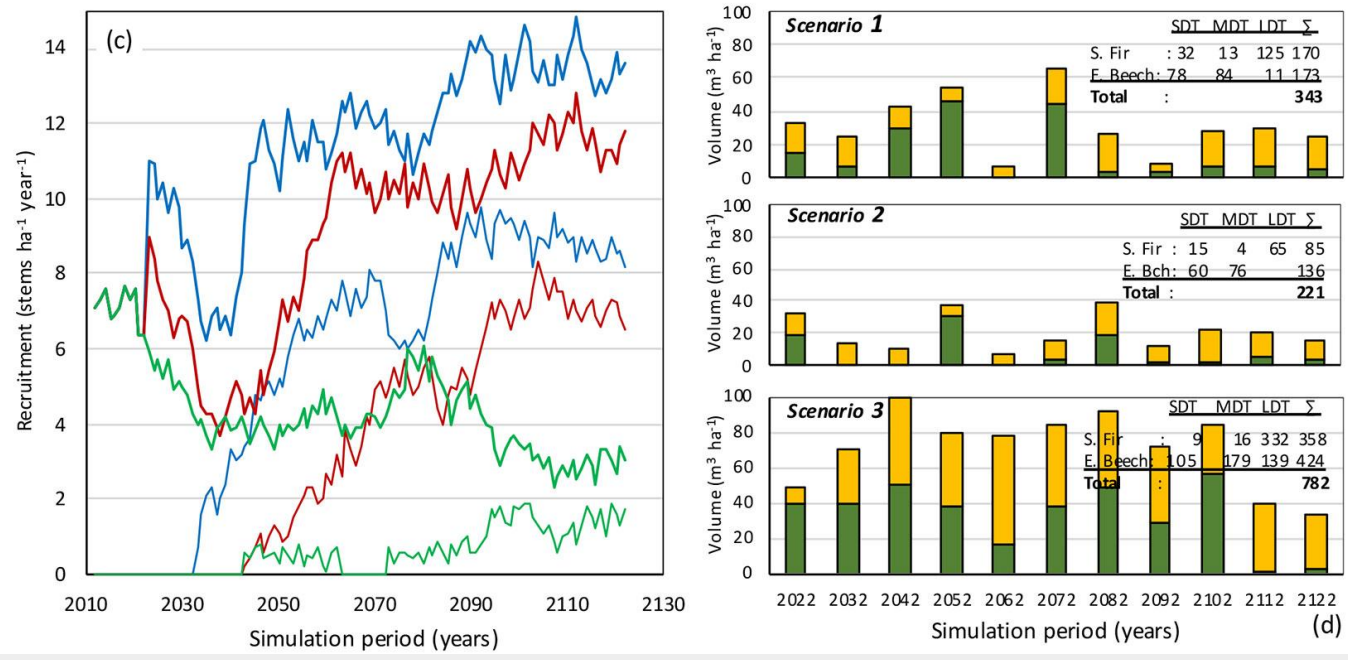

considerable decrease in standing volume and a change in the stand structure are expected based on Scenarios 1 and 2 (Tab. 2, Fig. 3b). Due to the large amount of harvesting in the first two cycles in Scenario 1, the standing volume of fir would be excessively decreased, whereas Scenario 2 predicts a gradual decrease in growing volume for fir (Fig. 3a). Scenario 1 and Scenario 2 showed similar trends of total standing volume in the last five cycles, almost coinciding with the theoretical BDq values. Harvesting would therefore focus on the largediameter firs and medium-diameter beech trees. On the contrary, a volume of dead trees lower than the gross volume increment within cycles (average $62 \%$ gross increment) predicted by Scenario 3 (no-management) would further increase standing volume to $1100 \mathrm{~m}^{3}$ per hectare (Tab. 2, Fig. 3b).

To better elucidate the effects of the simulated management regimes on the stand structure dynamics, we compared the DBH distribution at the beginning and the end of the simulation period with that obtained from the theoretical function (BDq) for fir (Fig. 2a) and for beech and other broadleaves (OB - Fig. 2b). Improved stand regeneration (Fig. $2 \mathrm{C}$ ) and increased tree di- ameter increment (i.e., a faster transition of trees into larger-diameter classes) would lead to an increased number of trees in the small DBH classes (fir and beech/OB) and the medium DBH classes (beech/OB) within Scenarios 1 and 2 and would result in approximately similar DBH distributions of fir and beech. The increased number of small-diameter firs, especially in the first two 5 -cm DBH classes (above theoretical values), and the removal of most large-diameter firs indicate fir regeneration. Scenario 1 would result in slightly better stand regeneration, as indicated by the higher number of recruited trees in the last three cycles (8.9 vs. 7.1 firs and 13.5 vs. 11.3 overall trees - Fig. 2c). According to the theoretical distribution, the remarkable absence of medium-diameter firs would continue. In contrast, relative to the beginning and theoretical distributions, the ending DBH distributions of beech and other broadleaf trees would shift to the right (i.e., towards larger diamaeters). The presence of very large $(\mathrm{DBH}>80 \mathrm{~cm})$ fir trees (44 per hectare) and medium and large beech/OB trees (94 per hectare) would be expected at the end of the simulation period under the no-management scenario (Scenario 3).
The relationship between the intensity and dynamics of harvesting and the amount of deadwood is reported in Fig. 2d. The more intensive harvest Scenario 2 would result in the least total volume of deadwood, amounting to $221 \mathrm{~m}^{3} \mathrm{ha}^{-1} 110$ years ${ }^{-1}$ with only $85 \mathrm{~m}^{3}$ of dead fir trees. Compared to Scenario 2, the volume of dead trees would be 3.5 times larger under the no-management scenario $\left(782 \mathrm{~m}^{3} \mathrm{ha}^{-1}\right)$ and would disproportionally reflect largediameter firs and medium-diameter beech/ OB trees (Fig. 2d).

The structure of the standing volume obtained at the end of the simulation period with respect to the initial and theoretical structures (Fig. 3C, Fig. 3d) shows differences among Scenarios 1, 2, and 3. The reference Scenario 1, with its less intensive harvest intensity, would result in a lower percentage of fir in the last cutting cycle ( $25 \%$ vs. $42 \%$ - Tab. 2, Fig. 3c, Fig. 3 d), which is especially noticeable in the middle $10-\mathrm{cm}$ DBH classes, where fir is almost absent. A large increase in volume and a shift in the DBH distribution, with fir prevailing the last three $10-\mathrm{cm}$ DBH classes (DBH $>80 \mathrm{~cm}$ ) and beech-OB prevailing in the previous DBH classes, would be achieved under the no-management approach (Scenario 3). 
Fig. 3 - Trends of observed and simulated standing volume for (a) Silver fir and (b) total standing volume over the period 1992-2122; (c) structure of beginning $v s$. theoretical stand volume (upper panel), and structure of stand volume at the end of the simulation period for Scenario 1 (lower panel); (d) structure of stand volume at the end of the simulation period for Scenario 2 (upper panel) and Scenario 3 (lower panel). All diagrams show the values after harvest.
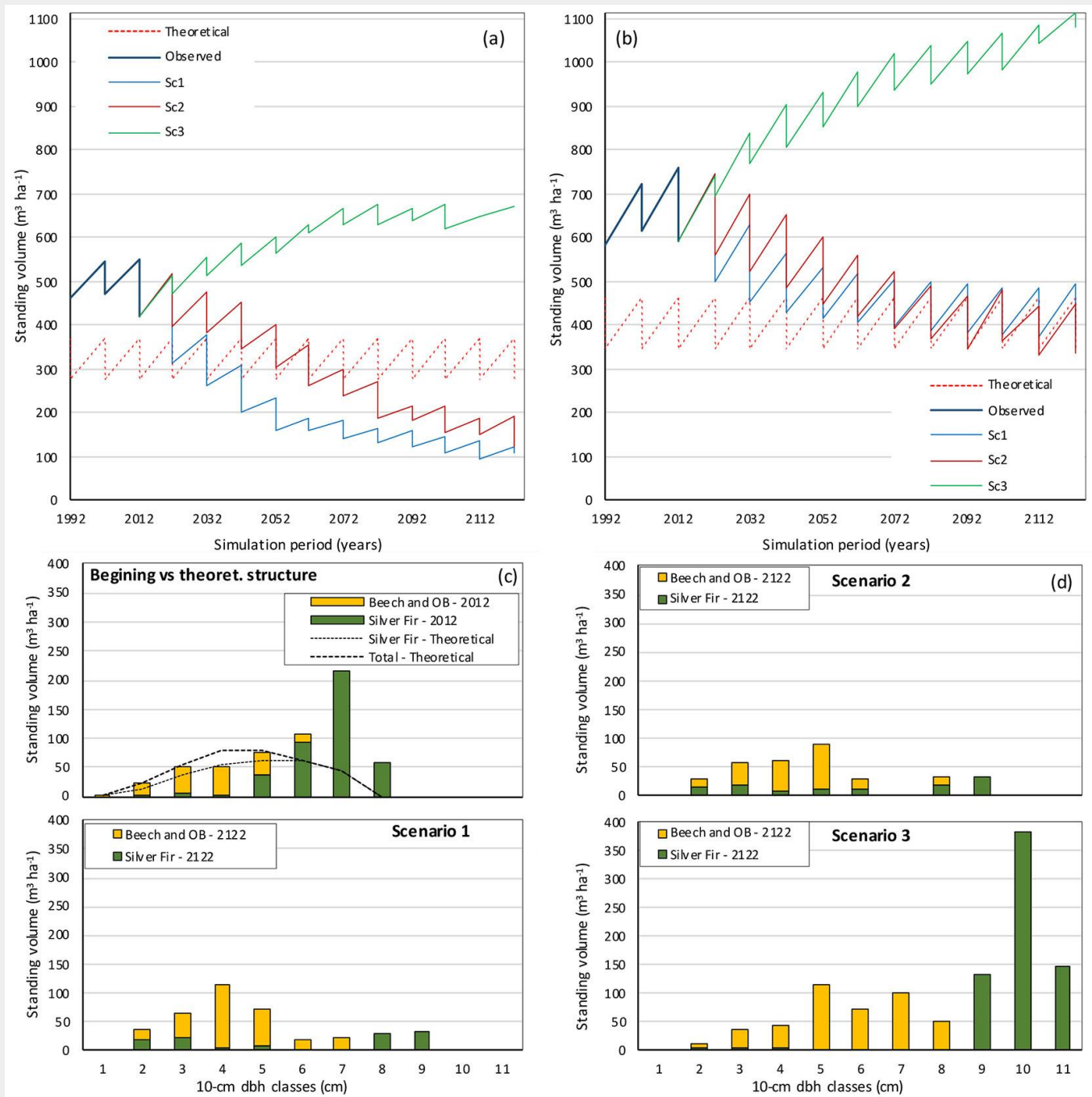

Tab. 3 - Indicators used in the evaluation of simulated management scenarios and their comparison with theoretical ("target") values. Indicators of management variables are not relevant for Scenario 3. ( $p$ ): rate of mean (current) annual volume increment; (INC): economic value ("on the stump") of trees to be felled; (n/r): not relevant; ( $I_{\mathrm{LDT}} F i r, I_{\mathrm{MDT}} F i$, $\left.I_{\mathrm{SDT}} F i r\right)$ : rate of large, medium and small silver fir diameter trees volume, respectively, according to the total theoretical volume; ( $\left.I_{\mathrm{LDT}} E B, I_{\mathrm{LDT}} E B, I_{\mathrm{LDT}} E B\right)$; rate of large, medium and small European beech and other broadleaves diameter trees volume, according to the total theoretical volume; ( $\left.I_{p} F i r, I_{p} E B\right)$ : ratio of an actual annual volume increment of silver fir/European beech according to the theoretical for each tree species; $\left(I_{\text {rcr }} F\right.$ ir, $\left.I_{\text {rcr }} E B\right)$ : ratio of actual recruitment of silver fir/European beech according to the theoretical recruitment for each tree species; $(*)$ : denote best ranking scenario for each indicator (simulated value closest to the theoretical value); (1): calculation includes the whole simulation period; (2): includes only the volume of trees to be felled (no dead trees); (3) the average value of the actual variables for the last three cycles was used to calculate the indicators.

\begin{tabular}{|c|c|c|c|c|c|c|c|c|}
\hline \multirow{2}{*}{$\begin{array}{l}\text { Variable } \\
\text { Group }\end{array}$} & \multirow{2}{*}{$\begin{array}{l}\text { Indicator } \\
\text { variable }\end{array}$} & \multirow{2}{*}{$\begin{array}{l}\text { Target } \\
\text { value }\end{array}$} & \multicolumn{2}{|c|}{ Scenario 1} & \multicolumn{2}{|c|}{ Scenario 2} & \multicolumn{2}{|c|}{ Scenario 3} \\
\hline & & & average & $\mathrm{I}_{\mathrm{DEV}}$ & average & $\mathrm{I}_{\mathrm{DEV}}$ & average & $\mathrm{I}_{\mathrm{DEV}}$ \\
\hline \multirow{4}{*}{ 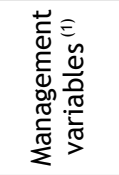 } & Harvest $^{(2)}\left(\mathrm{m}^{3} \mathrm{ha}^{-1} 10 \mathrm{yr}^{-1}\right)$ & 117.2 & 99.7 & 0.35 & 119.1 & $0.2^{*}$ & $\mathrm{n} / \mathrm{r}$ & $n / r$ \\
\hline & $\mathrm{hl}_{10}(\%)$ & 25.4 & 24 & 0.13 & 25.4 & $0.01^{*}$ & $n / r$ & $\mathrm{n} / \mathrm{r}$ \\
\hline & $\mathrm{p}(\%)$ & 2.54 & 2.07 & 0.19 & 2.14 & $0.17^{*}$ & 1.22 & 0.52 \\
\hline & INC (eur ha-1 10yr $\left.{ }^{-1}\right)$ & 4435 & 4043 & 0.33 & 4667 & $0.16^{*}$ & $\mathrm{n} / \mathrm{r}$ & $\mathrm{n} / \mathrm{r}$ \\
\hline \multirow{10}{*}{ 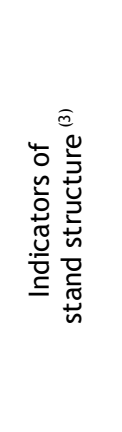 } & $\mathrm{I}_{\mathrm{LDT}} \mathrm{Fir}$ & 0.31 & - & 0.18 & - & $0.3^{*}$ & - & 1.85 \\
\hline & $I_{M D T} F i r$ & 0.35 & - & 0.01 & - & $0.04^{*}$ & - & 0 \\
\hline & $\mathrm{I}_{\mathrm{SDT}} \mathrm{Fir}$ & 0.15 & - & $0.11^{*}$ & - & 0.08 & - & 0.02 \\
\hline & $\mathrm{I}_{\mathrm{LDT}} \mathrm{EB}$ & 0 & - & $0.09^{*}$ & - & 0.25 & - & 0.62 \\
\hline & $I_{M D T} E B$ & 0.12 & - & 0.48 & - & $0.22^{*}$ & - & 0.38 \\
\hline & $\mathrm{I}_{\mathrm{SDT}} \mathrm{EB}$ & 0.08 & - & 0.23 & - & $0.12^{*}$ & - & 0.12 \\
\hline & $\mathrm{I}_{\mathrm{p}} \mathrm{Fir}$ & 1 & - & $0.86^{*}$ & - & 0.79 & - & 0.18 \\
\hline & $\mathrm{I}_{\mathrm{p}} \mathrm{EB}$ & 1 & - & $0.93^{*}$ & - & 1.26 & - & 0.47 \\
\hline & IrcrFir & 1 & - & 1.2 & - & $0.96^{*}$ & - & 0.19 \\
\hline & $\mathrm{I}_{\mathrm{Ircr}} \mathrm{EB}$ & 1 & - & 1.1 & - & $1.01^{*}$ & - & 0.42 \\
\hline
\end{tabular}


Although the reference Scenario 1 had ap proximately similar trends and stand struc ture development (Fig. 2, Fig. 3), our simulations show that the management Scenario 2 would be more suitable (Tab. 3). Indeed, the average values of management variables are closer to the target values, showing less deviation over the simulation period, and the indicators of stand struc ture variables are closer to theoretical rate. Finally, Scenario 3 (no-management) showed the highest discrepancies in stand structure indicators with respect to theoretical (balanced) stand structure, which is also assumed to be economically efficient.

\section{Discussion}

This study aimed to explore the influence of different management regimes on stand dynamics in high-stocked stands. The study was based on an available small permanent sample plot 0.36 ha in size, which was representative of the stand structure charac teristics. Generally, small plots have smaller number of trees, a larger edge effect, and do not include large tree clusters. Accord ingly, tree spatial patterns are generally as sessed on plots of at least 0.25 ha (Hanewinkel 2004). On the other hand, Carrer et al. (2018) suggested plots larger than one hectare to investigate large-scale spatial patterns and achieve high accuracy for long-distance patterns $(>10 \mathrm{~m})$ in oldgrowth mountain forests across Europe. In the study plot at the beginning of the simu lation period, several (up to six) tree clus ters (Fig. 1a) could be distinguished, indicating the existence of a lower limit for long-distance patterns. However, simulation of scenarios under different management regimes (Scenarios 1 and 2) based on single-stem and small-group selection (small canopy openings) would reveal even shorter-distance patterns and fine spatial structure. Regarding the assessment of stand structure attributes, Gray (2003) studied the plot size effect in old-growth and mature Douglas-fir forests, revealing that the density of small, medium, and large trees (75-122 cm DBH) estimated on four clustered sub-plots of $18 \mathrm{~m}$ radius each within a 1-ha plot (40.7\%) differed by $10 \%-20 \%$ in relation to the reference 1 -ha plot density. Based on similar size ( 0.36 vs. $0.41 \mathrm{ha}$ ), a similar degree of representativeness of the 1-ha stand area for the studied plot can be assumed. Hence, due to the above issues on plot size and its consequent limitations, the obtained, observed, and simulated results of this study are somewhat inconsistent, and the following considerations should be taken with caution.

Unlike the observed (Tab. 1) and tradition ally applied low harvest intensities, the ref erence and theoretical harvest intensity scenarios showed that more intense harvesting and stand openings would lead to the achievement of a balanced stand struc ture in the long term. According to Ray mond et al. (2018), who graded harvest in- tensities as light (20\%), moderate (31\%) and heavy $(42 \%)$ in a study of temperate mixedwood stands, the Scenario 2 can be categorized as moderate harvesting and the reference Scenario 1 as light harvesting. Moderate harvest intensity and more intense selection cuttings are needed to improve the stand structure by providing better light conditions for potential regeneration of various tree species, as recommended in several studies (Lafond et al. 2015, Raymond et al. 2018). Although the absolute theoretical selection structure at the tree species level would not be achieved even after 110 years (Fig. 2a, Fig. 2b), a relative theoretical selection structure with a surplus of thin-diameter trees is expected to occur in the long run.

Significant changes in diameter structure, tree species composition, and stand volume over the long term have been reported in many studies of the past dynamics of selection forests. Bončina et al. (2014), in a study of Dinaric uneven-aged forests in the NW Balkans, revealed a permanent increase in stand volume and large-diameter trees in managed forests. Similarly, an increase in stand basal area, a decrease in the number of trees per ha, and a substantial increase in the number of large-diameter firs were observed in other studies (O'Hara et al. 2007, Keren et al. 2018). Increases in the proportion of beech and other species were also noticed (Parobekova et al. 2018). These findings are consistent with the results of this study (Tab. 1). However, according to the simulated results (Scenario 1, Scenario 2 - Tab. 2), large decreases in overall stand volume and the volume of large-diameter trees as well as large increases in beech and sycamore maple are expected. The large increases of the latter species corresponds with the results of Mina et al. (2017), who reported a strong rise in the proportion of beech in the Dinaric Mountains under both management and climate change impacts over the long term.

Despite the overstocked stand structure observed in this study, poor fir regeneration in the past period and more recently as well as the abundance of regeneration and small-diameter beech trees (Tab. 1, Fig. $2 a$, Fig. $2 b$ ) indicate a long-term expansion of beech at the expense of fir, as already revealed by many studies (Bončina et al. 2002, 2014, Diaci et al. 2011). However, in forests characterized by high structural heterogeneity and tree species mingling (Keren et al. 2018), better conditions for development of young firs under older beech trees may be expected. Stand structure and canopy openings are considered as the key influential factors of stand regeneration (Čavlović et al. 2006, Raymond et al. 2018, Dobrowolska \& Bolibok 2019). Besides stand structure, environmental factors (i.e., site condition, climate, browsing) can strongly impact fir regeneration. Šafar (1965) revealed that fir is less competitive than beech in sites with slow de- composition of accumulated litter due to stand overstocking and dry micro-site condition. The impact of climate on fir regeneration was studied by Dobrowolska \& Bolibok (2019), who found that climatic variables (summer heat, moisture) are significant for predicting the probability of fir regeneration. Although the impact of ungulate browsing in limiting fir regeneration has been documented in Central Europe (Motta 1996, Klopčić et al. 2010, Fischer et al. 2013), this has minor impacts in the Gorski kotar region in Croatia due to controlling densities of red deer population (up to 1.5 per $\mathrm{km}^{2}$ - Malnar 2011), which is quite low compared to more than six red deer individuals per $\mathrm{km}^{2}$ reported for Slovenia (Klopčić et al. 2010). However, due to the unpredictability of dynamics and the influence of many ecological and other influential factors on stand regeneration, longterm projections of tree recruitment are less trustworthy.

Projection of the diameter structure of stands with respect to its theoretical expectations represents a powerful explanatory tool for decision-making in forest management. However, the present study could not consider the long-term influence of changes in climatic conditions and other influential factors. Yet, long-term predictions suggested a significant decrease in potential fir habitat in Croatia due to climate change (Anić et al. 2009), as well as improved growing conditions for beech at higher elevations compared to the current climate (Mina et al. 2017). Other environmental factors may also influence future stand dynamics (Kienast et al. 1999, Fischer et al. 2013).

Besides the achievement and maintenance of economically efficient stand structures, the functionality of stand structures should also be considered, as the goals of a multi-objective forest management are affected by currently changing environmental, social, and economic conditions. Bončina et al. (2014) highlighted an important advantage of uneven-aged forest management under increasingly unpredictable conditions, which is due to the "elasticity" of the structure of selection stands. Sustainability of uneven-aged management in a multi-objective sense based on different sites and uneven-aged management systems were confirmed in several studies (O'Hara et al. 2007, Lafond et al. 2015). The alternative to these harvest management approaches may be the maintenance of old-growth stands in specific parts of the fir-beech forest by applying a light-harvesting or no-harvest regime, with the objective of increasing the share of large trees and deadwood (Fig. 2d, Fig. 3d) and supporting ecological and forest habitat functions (Hodge \& Peterken 1998, Paillet et al. 2017). To this end, our projections showed that the adoption of a no-harvest regime (Scenario 3) would result in a considerably larger amount of deadwood compared with the other two harvesting scenarios 
(Scenarios 1 and 2 - Fig. 2d). This suggests that decreasing management intensity will favor the accumulation of deadwood and the provision of different habitat functions. The importance of old-growth forests for maintaining biodiversity and mitigating climate change has become more apparent, with many studies published recently (Frey et al. 2016, Watson et al. 2018, Kenina et al. 2019). The results obtained in this study show that in such high-stocked stands or parts of stands, only several decades (up to 5) would be needed to achieve old-growth structural characteristics (Bauhus et al. 2009). Hence, such stands represent an appropriate basis for establishing networks of managed multifunctional forest ecosystems.

The influence of the proportion and size of canopy gaps in different types of stands on the dynamics and structure of selection stand regeneration is a key issue which deserves further investigations. Parobekova et al. (2018) showed that in a mixed sprucefir-beech old-growth forest, only canopy gaps $>100 \mathrm{~m}^{2}$ formed by the mortality of a single tree or small group of trees were of major importance for the extensive establishment of natural regeneration. In our study, due to the relatively small size of the sample plot, only single-stem and combinations of single-stem and small-group crown openings were simulated. Therefore, it may be more appropriate the use of larger "virtual" plots (Beljan et al. 2018) that integrates several NFI sample plots within a specific site, stand characteristics, and previous management regimes.

\section{Conclusions}

The results of our study can support its starting hypotheses, despite the limitations discussed above. The projected stand structure based on simulations of different management regimes showed that a more intensive selection harvest would positively affect stand regeneration dynamics, favoring the achievement of the targeted selection stand structure in at least 100 years, assuming the absence of influences from any other factors.

The approach traditionally used in operational forest planning based on the actual rate of current annual increment has not led to as "poor" a harvest intensity approach as expected, due to the initial overstocked conditions of the stand. However, the results obtained indicated that the reference approach was less suitable than the others. On the contrary, the theoretical harvest intensity approach was deemed as the more appropriate according to both management and stand structure variables. Hence, the permanent application of this approach can be recommended in the long run, independently of the structural characteristics of the selection stand.

This study investigated for the first time the dynamics of past stand development and long-term projections of high-stocked stand structure and its regeneration under different management regimes in the firbeech forest type in the Croatian Dinarides. The results obtained may be useful to support the conversion of high-stocked stands to a balanced structure, as well as to achieve old-growth structure in the Dinaric region. However, further comprehensive investigations are needed, including plots representing different site-stand characteristics, forest types, and previous management regimes. Various selection management systems, management objectives, and environmental factors (climate, emissions, disturbances) should also be included to support planning and management in fir-beech forests.

\section{Acknowledgments}

K.T., K.B., M.V., M.A. and J.C. designed the study; K.T., M.V. and K.B. collected the field data; K.T., and K.B. analysed the data; J.C wrote final draft of the manuscript. All authors contributed in revising and editing the manuscript. This research was funded by the Croatian Science Foundation (project no. IP-2018-01-8820).

\section{References}

Anić I, Vukelić J, Mikac S, Bakšić D, Ugarković D (2009). Effects of global climate change on the ecological niche of silver fir (Abies alba Mill.) in Croatia. Šumarski List 133: 135-144. [online] URL: http://hrcak.srce.hr/36397

Bauhus J, Puettmann K, Messier C (2009). Silviculture for old-growth attributes. Forest Ecology and Management 258: 525-537. - doi: 10.101 6/j.foreco.2009.01.053

Beljan K, Posavec S, Čavlović J, Teslak K, Knoke T (2018). Economic consequences of different approaches to even-aged silver fir forests. Croatian Journal of Forest Engineering 39: 299-312. [online] URL: http://hrcak.srce.hr/204197?lang= en

Bettinger $\mathrm{P}$, Boston $\mathrm{K}$, Siry JP, Grebner DL (2009). Forest management and planning. Academic Press, London, UK, pp. 331.

Bončina A, Diaci J, Cenčić L (2002). Comparison of the two main types of selection forests in Slovenia: distribution, site conditions, stand structure, regeneration and management. Forestry 75: 365-373. - doi: 10.1093/forestry/75. 4.365

Bončina A (2011). History, current status and future prospects of uneven-aged forest management in the Dinaric region: an overview. Forestry 84: 467-478. - doi: 10.1093/forestry/cpro23 Bončina A, Čavlović J, Curović M, Govedar Z, Klopčič M, Medarević M (2014). A comparative analysis of recent changes in Dinaric unevenaged forests of the NW Balkans. Forestry 87: 71-84. - doi: 10.1093/forestry/cpt038

Bozić M (1999). Modeli gospodarenja šumama jele u Gorskom kotaru [Models of silver fir forest management in Gorski Kotar region]. MSC thesis, Dept. of Forest Inventory and Management, Faculty of Forestry, University of Zagreb, Croatia, pp. 120. [in Croatian]

Carrer M, Castagneri D, Popa I, Pividori M, Lingua $E$ (2018). Tree spatial patterns and stand attributes in temperate forests: the importance of plot size, sampling design, and null model.
Forest Ecology and Management 407: 125-134. doi: 10.1016/j.foreco.2017.10.041

Čavlović J, Bozić M, Bončina A (2006). Stand structure of an uneven-aged fir-beech forest with an irregular diameter structure: modeling the development of the Belevine forest, Croatia. European Journal of Forest Research 125: 325-333. - doi: 10.1007/s10342-006-0120-z Čavlović J, Božić M, Teslak K, Vedriš M (2016). Chapter 15 - Croatia. In: "National Forest Inventories - Assessment of Wood Availability and Use" (Vidal C, Alberdi I, Hernandez L, Redmond J eds). Springer, Cham, Switzerland, pp. 281305.

Diaci J, Rozenbergar D, Anić I, Mikac S, Saniga M, Kucbel S, Visnjic C, Ballian D (2011). Structural dynamics and synchronous silver fir decline in mixed old-growth mountain forests in Eastern and Southeastern Europe. Forestry 84: 479-491. - doi: 10.1093/forestry/cpro3o

Dobrowolska D, Bolibok L (2019). Is climate the key factor limiting the natural regeneration of silver fir beyond the northeastern border of its distribution range? Forest Ecology and Management 439: 105-121. - doi: 10.1016/j.foreco.20 19.02 .040

Emmingham WH (2002). Status of uneven-aged management in the Pacific Northwest, USA. Forestry 75: 433-436. - doi: 10.1093/forestry/75. 4.433

Ficko A, Poljanec A, Bončina A (2011). Do changes in spatial distribution, structure and abundance of silver fir (Abies alba Mill.) indicate its decline? Forest Ecology and Management 261: 844-854. - doi: 10.1016/j.foreco.2010.12.014 Fischer A, Marshall P, Camp A (2013). Disturbances in deciduous temperate forest ecosys tems of the Northern Hemisphere: their effects on both recent and future development. Biodiversity and Conservation 22: 863-898. - doi: 10.1007/s10531-013-0525-1

Frey SJK, Hadley AS, Johnson SL, Schulze M, Jones JA, Betts MG (2016). Spatial models reveal the microclimatic buffering capacity of oldgrowth forests. Science Advances 2 (4): e1501392. - doi: 10.1126/sciadv.1501392

Gray A (2003). Monitoring stand structure in mature coastal Douglas-fir forests: effect of plot size. Forest Ecology and Management 175: 1-16. - doi: 10.1016/S0378-1127(02)00078-6

Hanewinkel M (2004). Spatial patterns in mixed coniferous even-aged, uneven-aged and conversion stands. European Journal of Forest Research 123 (2): 139-155. - doi: 10.1007/s10342-00 4-0023-9

Hanewinkel M, Frutig F, Lemm R (2014). Economic performance of uneven-aged forests analysed with annuities. Forestry 87: 49-60. - doi: 10.1093/forestry/cpto43

Hodge SJ, Peterken GF (1998). Deadwood in British forests: priorities and strategy. Forestry 71: 99-112. - doi: 10.1093/forestry/71.2.99

Hasenauer $\mathrm{H}$, Kindermann $\mathrm{G}$, Steinmetz $\mathrm{P}$ (2006). The tree growth model MOSES 3.0. In: "Sustainable Forest Management Growth Models for Europe ( $1^{\text {st }}$ edn)" (Hasenauer $\mathrm{H}$ ed). Springer, Berlin, Germany, pp. 64-70.

Kenina L, Jaunslaviete I, Liepa L, Zute D, Jansons A (2019). Carbon pools in old-growth Scots pine stands in hemiboreal Latvia. Forests 10: 1-10. doi: 10.3390/f10100911 
Keren S, Medarević M, Obradović S, Zlokapa B (2018). Five decades of structural and compositional changes in managed and unmanaged montane stands: a case study from South-East Europe. Forests 9: 2-19. - doi: 10.3390/f9080479 Kienast F, Fritschi J, Bissegger M, Abderhalden $W$ (1999). Modeling successional patterns of high-elevation forests under changing herbivore pressure - responses at the landscape level. Forest Ecology and Management 120: 35-46. - doi: 10.1016/S0378-1127(98)00541-6

Klepac D (1961). Novi sistem uredivanja prebornih šuma [New management system of uneven aged forests]. Komora poljoprivrede i šumarstva NR Hrvatske, Zagreb, Croatia, pp. 46. [in Croatian]

Klopčić M, Jerina K, Bončina A (2010). Long-term changes of structure and tree species composition in Dinaric uneven-aged forests: are red deer an important factor? European Journal of Forest Research 129: 277-288. - doi: 10.1007/s103 42-009-0325-z

Lafond V, Cordonnier T, Courbaud B (2015). Reconciling biodiversity conservation and timber production in mixed uneven-aged mountain forests: identification of ecological intensification pathways. Environmental Management 56: 1118-1133. - doi: 10.1007/s00267-015-0557-2

Linares J, Camarero JJ (2012). Growth patterns and sensitivity to climate predict silver fir decline in the Spanish Pyrenees. European Journal of Forest Research 131: 1001-1012. - doi: 10.10 07/s10342-011-0572-7

Malnar J (2011). Migracije običnog jelena (Cervus elaphus L.) u zapadnom dijelu Gorskog kotara kao odraz stanišnih čimbenika [The migration of red deer (Cervus elaphus L.) in the western part of Gorski Kotar as a reflection of habitat factors]. PhD thesis, Faculty of Forestry, Zagreb University, Croatia, pp. 187. [in Croatian]

Meyer HA (1943). Management without rotation. Journal of Forestry 41: 126-132. [online] URL: http://academic.oup.com/jof/article-abstra ct/41/2/126/4706846

Mikac S, Klopf M, Anić I, Hasenauer H (2013). Using the tree growth model MOSES to assess the dynamics of Dinaric old-growth mixed beech-fir forest ecosystems. Plant Biosystems 147: 664-671. - doi: 10.1080/11263504.2013.7766 49

Mina $M$, Bugmann $H$, Klopčić $M$, Cailleret $M$ (2017). Accurate modeling of harvesting is key for projecting future forest dynamics: a case study in the Slovenian mountains. Regional Environmental Change 17: 49-64. - doi: 10.1007/s10 113-015-0902-2

Motta R (1996). Impact of wild ungulates on forest regeneration and tree composition of mountain forests in the Western Italian Alps. Forest Ecology and Management 88: 93-98. doi: 10.1016/S0378-1127(96)03814-5

O'Hara KL, Hasenauer H, Kindermann G (2007). Sustainability in multi-aged stands: an analysis of long-term plenter systems. Forestry 80: 163178. - doi: 10.1093/forestry/cplo51

O'Hara KL, Gersonde RF (2014). Stocking control concepts in uneven-aged silviculture. Forestry 77 (2): 131-143. - doi: 10.1093/forestry/77.2.131

O’Hara KL, Bončina A, Diaci J, Anić I, Boydak M, Curović M, Govedar Z, Grigoriadis N, Ivojevic S, Keren S, Kola H, Kostov G, Medarević M, Metaj M, Nicolescu N, Raifailov G, Stancioiu P, Velkovski N (2018). Culture and silviculture: origins and evolution of silviculture in Southeast Europe. International Forestry Review 20 (1): 130143. - doi: $10.1505 / 146554818822824228$

Paillet Y, Archaux F, Boulanger V, Debaive N, Fuhr M, Gilg O, Gosselin F, Guielbert E (2017). Snags and large trees drive higher tree microhabitat densities in strict forest reserves. Forest Ecology and Management 389: 176-186. doi: 10.1016/j.foreco.2016.12.014

Parobekova Z, Pittner J, Kucbel S, Saniga M, Filipek M, Sedmakova D, Vancurik J, Jaloviar $P$ (2018). Structural diversity in a mixed spruce-firbeech old-growth forest remnant of the Western Carpathians. Forests 9: 2-19. - doi: 10.3390/f 9070379

Pirovano AR, Zecca G (2014). Black woodpecker Dryocopus martius habitat selection in the Italian Alps: implications for conservation in Natura 2000 network. Bird Conservation International 24: 299-315. - doi: 10.1017/So95927091300 0439
Raymond P, Royo A, Prevost M, Dumais D (2018). Assessing the single-tree and small group selection cutting system as intermediate disturbance to promote regeneration and diversity in temperate mixedwood stands. Forest Ecology and Management 430: 21-32. - doi: 10.1016/j.foreco.2018.07.054

Regulations for Forest Management Planning (2006). Pravilnik o uređivanju šuma [Rules on forest management]. Narodne Novine, 111/ 2006, Zagreb, Croatia. [in Croatian] [online] URL: http://narodne-novine.nn.hr/clanci/sluzbe ni/2006_10_111_2462.html

Rozenbergar D, Mikac S, Anić I, Diaci J (2007). Gap regeneration patterns in relationship to light heterogeneity in two old-growth beech-fir forest reserves in South East Europe. Forestry 80: 432-443. - doi: 10.1093/forestry/cpmo37

Šafar J (1965). Sirenje bukve na području Dinarida u Hrvatskoj [The expanding emergence of beech in Croatian Dinarides]. Šumarski List 89: 198-217. [in Croatian]

Špiranec M (1976). Volumne tablice za jelu i smreku [Volume tables for silver fir and Norway spruce]. Radovi 29: 1-119. [in Croatian]

Watson JEM, Evans T, Venter O, Williams B, Tulloch A, Stewart C, Thompson I, Ray JC, Murray K, Salazar A, McAlpine C, Potapov P, Walston J, Robinson JG, Painter M, Wilkie D, Filardi C, Laurance WF, Houghton RA, Maxwell S, Grantham $\mathrm{H}$, Samper C, Wang S, Laestadius L, Runting RK, Silva-Chávez GA, Ervin J, Lindenmayer D (2018). The exceptional value of intact forest ecosystems. Nature Ecology and Evolution 2 (4): 599610. - doi: 10.1038/s41559-018-0490-x

\section{Supplementary Material}

Fig. S1 - Map of the Gorski kotar forest region and research site location.

Tab. S1 - Overview of general and stand structure characteristics of the studied selection fir-beech forests in Gorski kotar region.

Link: Cavlovic_3638@supploo1.pdf 